\title{
Physico-Chemical and Microbiological Qualities of Water From Wells, Drillings and Tanks Used as Drinking Water in the Municipality of Allada (Benin, West Africa)
}

\section{Sohounou Marc}

Laboratory of Research in Biochemistry and Toxicology of the environment (LaRBiTE), Department of Biochemistry and Cellular Biology, Faculty of Sciences and Techniques (FAST), University of Abomey-Calavi (UAC), BP 2899 Abomey-calavi, Benin

Department of Geography and regional development, Faculty of Letters, Arts and Humanities (FLASH), University of Abomey-calavi,

BP 2899 Abomey-Calavi, Benin

National Water Institute, University of Abomey, Box 526 Cotonou, Benin

\section{Vissin Expédit Wilfrid}

Pierre PAGNEY Laboratory: Climate, Water, Ecosystems and Development (LaCEEDE), Faculty of Letters, Arts and Humanities (FLASH), University of Abomey- Calavi 01 BP 526, Cotonou

Department of Geography and regional development, Faculty of Letters, Arts and Humanities (FLASH), University of Abomey-calavi,

BP 2899 Abomey-Calavi, Benin

\section{Sintondji Luc Olivier}

National Water Institute, University of Abomey, Box 526 Cotonou, Benin Houssou Christophe S.

Pierre PAGNEY Laboratory: Climate, Water, Ecosystems and Development (LaCEEDE), Faculty of Letters, Arts and Humanities (FLASH), University of Abomey- Calavi 01 BP 526, Cotonou

Department of Geography and regional development, Faculty of Letters, Arts and Humanities (FLASH), University of Abomey-calavi, BP 2899 Abomey-Calavi, Benin

\section{Agbossou K. Euloge}

National Water Institute, University of Abomey, Box 526 Cotonou, Benin

\section{Edorh A. Patrick}

Laboratory of Research in Biochemistry and Toxicology of the environment (LaRBiTE), Department of Biochemistry and Cellular Biology, Faculty of Sciences and Techniques (FAST), University of Abomey-Calavi (UAC), BP 2899 Abomey-calavi, Benin 


\section{Abstract}

Water, source of life, is also a source of disease when it is polluted. The aim of this study is to analyze the physicochemical quality and the bacteriological quality of the wells, boreholes and tank for drinking water in the Commune of Allada. The methodology is based on the collection of data, data processing and analysis carried out at the Laboratory for Quality Control of Water and Food (LCQEA) of the Ministry of Health. From the water sampling carried out at three (03) traditional wells, two (02) boreholes, two (02) tanks and water of river (02), bacteriological and physicochemical analysis were performed. The results showed that $\mathrm{pH}$ is higher at the tank than other water sources. Well 3 (P3) has a very high electrical conductivity (EC) which was $384.95 \mu \mathrm{S} / \mathrm{cm}$ and $192.47 \mathrm{mg} / \mathrm{L}$ for total dissolved solids (TDS). The tank 2 exhibited high value in $\mathrm{pH} 9.14 ; 71.72(\mu \mathrm{S} / \mathrm{cm})$ for the electrical conductivity (CE) and $35.86 \mathrm{mg} / \mathrm{L}$, in total dissolved solids (TDS). Well 2 (P2) has a high turbidity of 4.53 (NTU) at all analyzed water points. The concentration of iron, copper nickel and cobalt remains low(less than $0.4 \mathrm{mg} / \mathrm{L}$ ).Wells 2 and tank 1 are concentrated in lead, respectively $20.75 \mathrm{mg} / \mathrm{L}$ and $13.71 \mathrm{mg} / \mathrm{L}$. Tank 1 and 2 have a high concentration of cadmium compared to other water points. The presence of Escherichia coli with a high concentration at home SONEB (39 CFU) and at well $2\left(7.10^{2}\right)$ was found. In view of these results some recommendations were made.

Keywords: Allada, Drinking water, physical pollution, microbiological pollution and quality.

\section{Introduction}

The majority of populations in developing countries use water and groundwater directly for their drinking water supply (Mpakam et al., 2006).

Drinking water is one of the basic needs of every living being. The survival of man requires a sufficient quantity of water, since water contributes to the proper functioning and balance of human physiology. This non-substitutable and life-saving resource must be seen as a natural treasure that is part of the common heritage of humanity (WHO, 2004).

Specific work has addressed the impact of poor sanitation on the quality of water resources in sub-Saharan African cities. This work highlights the bacteriological and nitrogen pollution of surface water and rivers (Nairain, 2002). Fecal microbiological contamination of water is a problem that has a major impact on water quality around the world, human pathogenic microorganisms such as viruses, bacteria, etc. 
The consumption of water contaminated by faeces therefore poses a serious risk to human health (Degbey et al., 2010). This water therefore constitutes vectors of germs originated from water. It is essential to analyze the water of its well, drilling and tank in order to know their quality.

The objective of this study is to determine the physico-chemical and microbiological quality of wells, boreholes and tank for drinking water in the municipality of Allada (Figure 1).

Figure 1: Administrative Situation of the Municipality of Allada
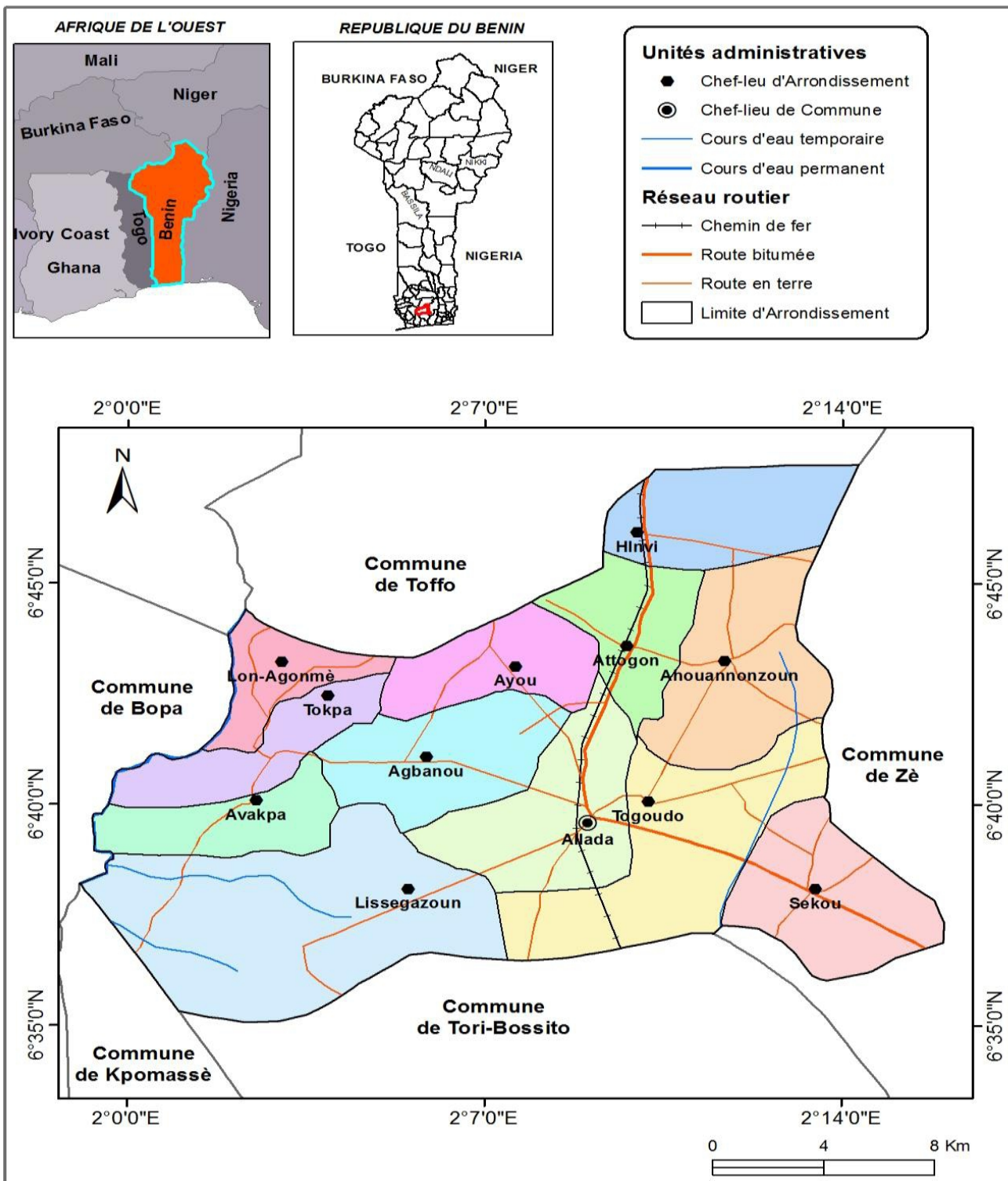

Données: SOHOUNOU Marc

Sources: Fond Topo IGN 1992, Image Landsat8 2014 Réalisation: Décembre 2016 


\section{Materials and Methods}

The physicochemical and microbiological characteristics of well and tank water were carried out at three (03) wells, two (02) tank, two (02) boreholes that were selected by simple random sampling in the rural districts Of the Commune of Allada (Figure 2). These water points are located by their geographical coordinates which have been determined through GPS (Global Position System) receiver of GARMIN type. From a physicochemical point of view, the risks are multiple. The excess of certain elements, such as nitrites, nitrates, sulphates, etc., cause diseases which may be very serious (Lanoix et al., 1976).

Figure 2: Water sampling sites

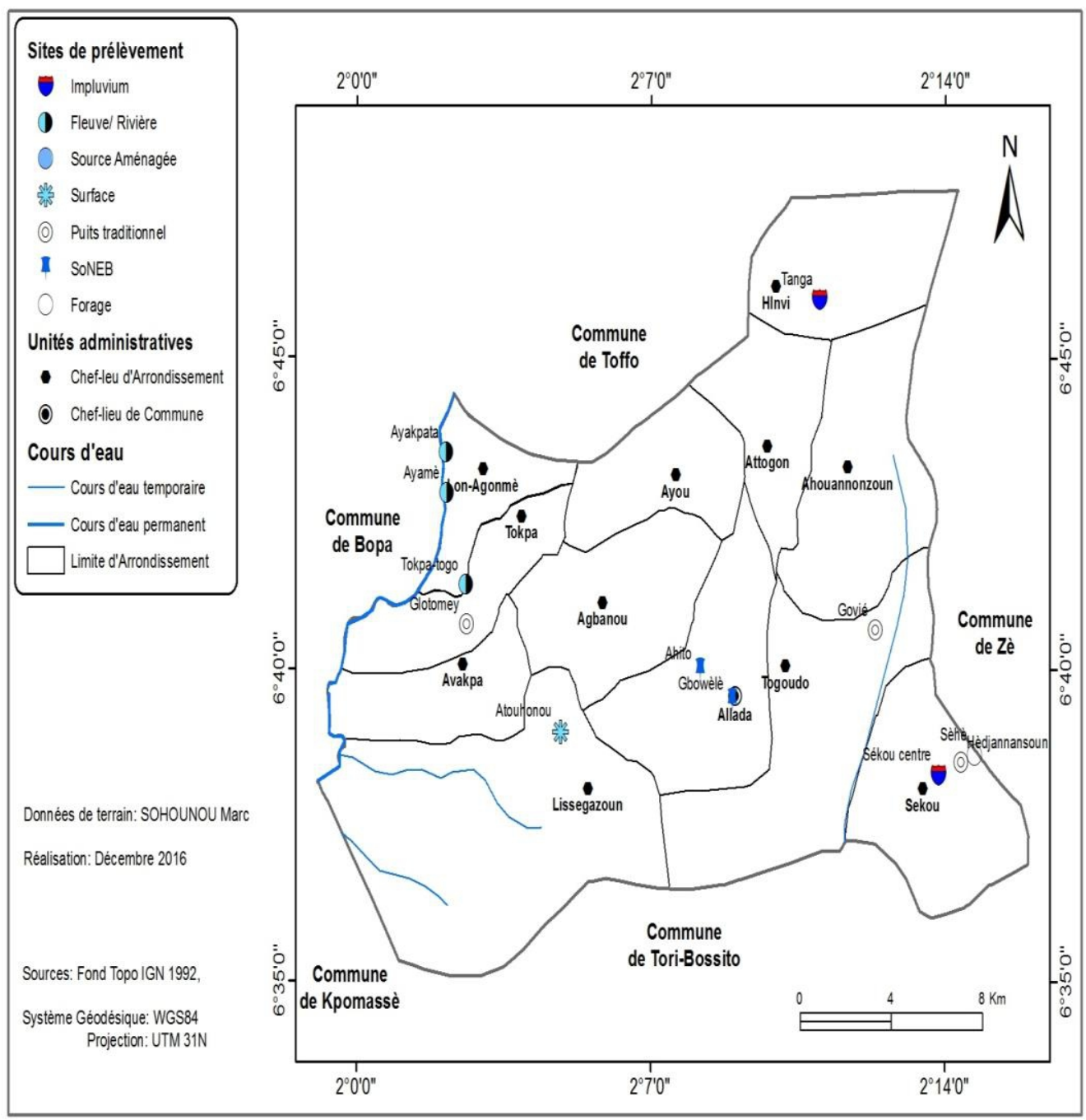




\section{Determination of physicochemical parameters}

The sampling in these water samples was carried out in bottles of possotomé (Photo 1) to which was fixed a string making it possible to lower them in the well or the tank. For drilling water, the tap is thoroughly cleaned and then sterilized before setting. Water samples collected in $1.5 \mathrm{~L}$ were stored in a refrigerated cooler $\left(4^{\circ} \mathrm{C}\right)$ until the time of analysis.

The physicochemical and microbiological parameters were monitored using the techniques of Rodier et al (2009). Temperature, hydrogen potential $(\mathrm{pH})$, electrical conductivity (CE), Total Dissolved Salt (TDS), etc., and some microbiological parameters were measured for drinking water quality.

Nitrates (NO3-), nitrites (NO2-), ammoniacal nitrogen (NH4 +), total iron $(\mathrm{Fe})$ and aluminum $(\mathrm{Al} 3+)$ were determined by colorimetric determination using a spectrophotometer (DR / 2800). Principal Component Analyzes were used to analyze the relationships between the parameters tested.

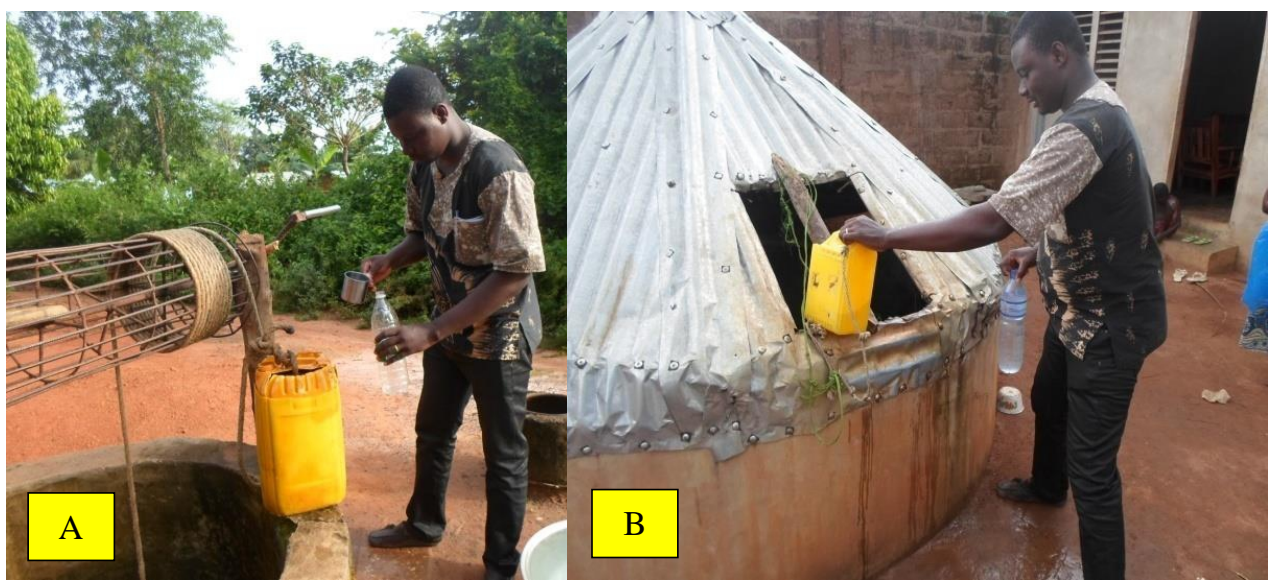

Photo 1 : Session of taking well water in big diameter at Sékou village (A) and tank at Hinvi (B)

Shooting: Idani, in November, 2016

\section{Determination of microbiological parameters}

The microbiological parameters of well water, drilling and impluvium are determined by bacteriological and parasitological analyzes. The existence of water-borne diseases has been recognized as a pathogenic, microbial agent that is often enteric (i.e linked to the intestines) and transported by water, in particular those that are worn and superficial (Festy et al., 2003). This agent may be of bacterial origin (salmonella, shigella, Escherichia coli and coliform bacilli, cholera vibrios, Legionella, etc.) or viral. It is necessary to research some of these germs in the water of wells sampled including E. Coli. 
The parasitological analysis was carried out on the pellet obtained after centrifugation at $4000 \mathrm{rpm}$ for 10 minutes of $5 \mathrm{~mL}$ of the sample taken in $5 \mathrm{~L}$ of the sample after 24 hours for the possible investigation of the parasites.

\section{Results}

Physico-chemical and microbiological qualities of drinking water in Allada

The quality of drinking water depends on the physicochemical and microbial parameters contained in these waters.

\section{Physical quality of sampled water}

Water temperature is an important factor in organic production. This is due to the fact that it affects the physical and chemical properties of the latter, in particular the density, viscosity, solubility of its gases (especially that of oxygen) and the rate of chemical and biochemical reactions (Hassoune et al., 2010).

The results of physical analyzes are summarized in Table I. These parameters have been analyzed and their values vary considerably from one source to another.

Table I: Physical parameters of the studied waters

\begin{tabular}{|c|c|c|c|c|c|c|c|c|c|c|c|c|}
\hline \multirow[t]{2}{*}{ Settings } & \multicolumn{2}{|c|}{ Temperature } & \multicolumn{2}{|c|}{ pH } & \multicolumn{2}{|c|}{$\begin{array}{c}\text { Electrical } \\
\text { conductivity }\end{array}$} & \multicolumn{2}{|c|}{$\begin{array}{c}\text { Total } \\
\text { Dissolved } \\
\text { Salts }\end{array}$} & \multicolumn{2}{|c|}{ Turbidity } & \multicolumn{2}{|c|}{ Color } \\
\hline & $\overline{\mathrm{VL}}$ & $\mathrm{N} \mathrm{N}$ & $\overline{\mathrm{VL}}$ & $\mathrm{NN}$ & $\mathrm{VL}$ & $\mathrm{N} \mathrm{N}$ & VL & $\mathrm{NN}$ & $\mathrm{VL}$ & $\begin{array}{l}\mathrm{N} \\
\mathrm{N}\end{array}$ & VL & $\begin{array}{l}\mathrm{N} \\
\mathrm{N}\end{array}$ \\
\hline Drilling 1 & 26.7 & & 5.56 & & 55.48 & & 27.74 & & 0.7 & & 1,55 & \\
\hline Drilling 2 & 26.1 & & 5.72 & & 79.89 & & 39.94 & & 0.83 & & $<0.01$ & \\
\hline Well 1 & 26.3 & & 6.12 & & 150.21 & & 75.11 & & 0.9 & & $<0.01$ & \\
\hline Well 2 & 26.4 & 25 & 6.24 & $\begin{array}{l}6.5 \\
\leq \\
\text { pH } \leq \\
8.5\end{array}$ & 111.29 & 2000 & 55.64 & 1000 & 4.53 & 5 & 18.7 & 15 \\
\hline Well 3 & 26.4 & & 6.39 & & 384.95 & & 192.47 & & 2.39 & & 3.55 & \\
\hline Tank 1 & 26.5 & & 6.89 & & 56.45 & & 28.22 & & 1.1 & & 0.23 & \\
\hline Tank 2 & 26.8 & & 9.14 & & 71.72 & & 35.86 & & 1.66 & & 4.37 & \\
\hline
\end{tabular}

Source: SOHOUNOU, in November, 2016; results of analysis of the Laboratory (LCQEA)

Legend: $\mathrm{N}$ = national standard, $\mathrm{VL}=$ value of laboratory, $\mathrm{Red}=$ exceptional value, Black = value respecting the standards

From the analysis of Table I, it appears that whatever source of drinking water, the temperature measured is higher. This temperature varies between 26.1 and $26.8^{\circ} \mathrm{C}$ from the national standard for drinking water at 
$25^{\circ}$ C. It follows then that all the samples analyzed have an unusual temperature. These results are consistent with those of Degbey et al. (2010). For $\mathrm{pH}$, it is also apparent that all sampled sources have a $\mathrm{pH}$ value below the nationally recognized limiting range. Only tank 1 respects the guideline value with 6.89. All sources have a slightly acid $\mathrm{pH}(\mathrm{pH}<6.5)$, except for tank 2 which has a basic $\mathrm{pH}$ with a value of 9.14. Conductivity for all sources meets the standard. Global mineralization varies from medium to high. We find that mineralization is more important in well water than in the waters of boreholes and tanks (Tanouayi et al., 2015). The same applies to dissolved total salts, turbidity and color which also comply with guide values. It should be pointed out that well 2 has a turbidity value to be monitored (4.53 against a normal of 5); the color also is 18.7 instead of 15 . Also there are certain practices of the indigenous population that participate in affecting the physical quality of the water. These include bushes around water points or lack of cleaning (photo 2).

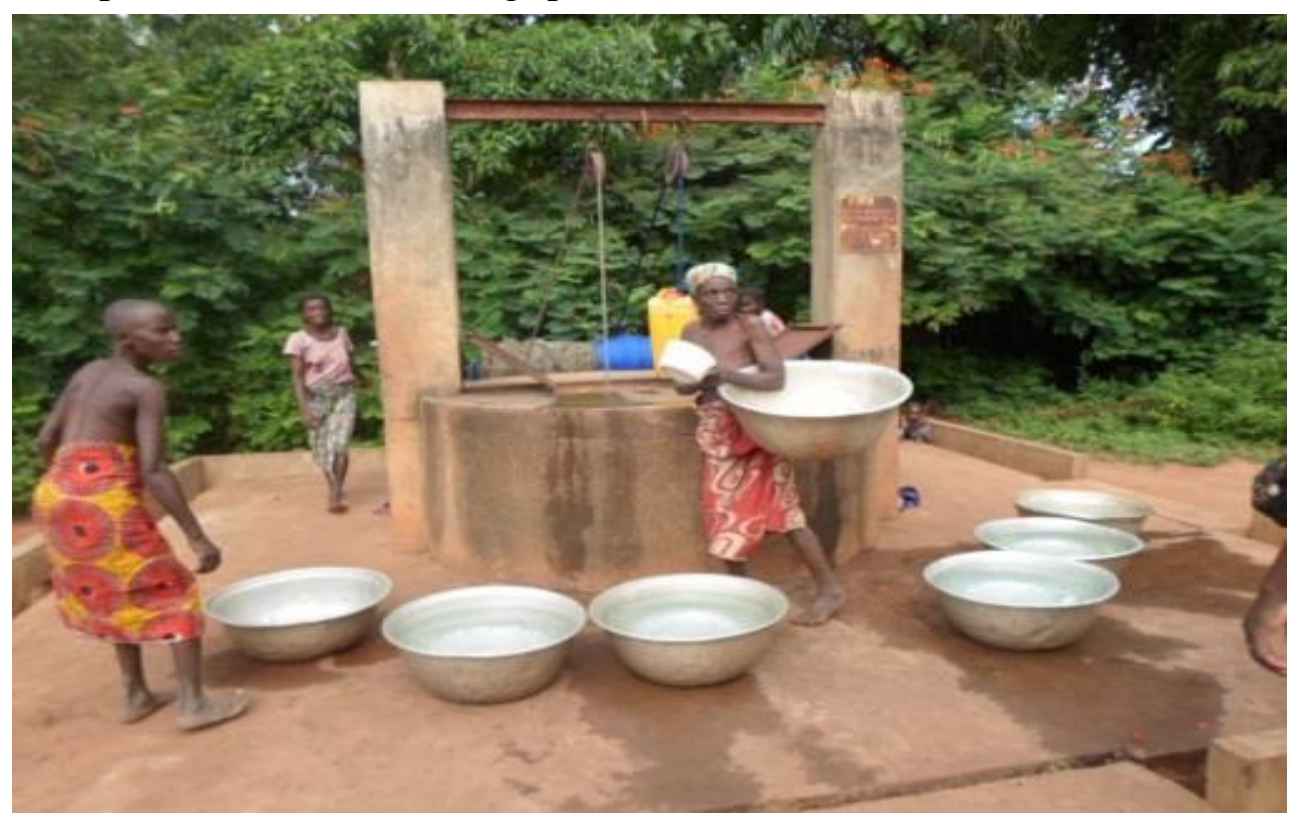

Photo 2: Women looking for drinking water at an unconditioned well in Lissègazoun

Shooting: Sohounou, in November, 2016

This photo shows that the surroundings of the well are covered with vegetation that is less than one meter. Contamination of the well with aerobic pathogens cannot be ignored since it is exposed to everything that happens in its environment. The rural environment vegetation serves as the place of feces, so the risk of faecal contamination. 


\section{Chemical quality of sampled waters}

The analysis revealed in some wells the presence of abnormal nitrate contents thus constituting an effective pollution that could harm the health of the consumer.

Table II : Results of analysis of chemical parameters

\begin{tabular}{|c|c|c|c|c|c|c|c|c|c|c|c|c|}
\hline Settings & $\begin{array}{c}\text { Uni } \\
\mathbf{t}\end{array}$ & $\begin{array}{c}\text { Symb } \\
\text { ol }\end{array}$ & Appliances & Methods & $\begin{array}{c}\text { Drilling } \\
1\end{array}$ & $\begin{array}{c}\text { Drilling } \\
2\end{array}$ & Well1 & Well2 & Well 3 & Tank1 & $\begin{array}{c}\text { Tank } \\
\mathbf{2}\end{array}$ & $\begin{array}{c}\text { Nationa } \\
1 \\
\text { Standar } \\
\text { d }\end{array}$ \\
\hline Nitrites & $\begin{array}{l}\mathrm{mg} \\
/ \mathrm{L}\end{array}$ & NO2- & $\begin{array}{l}\text { Spectrophoto } \\
\text { mètre }\end{array}$ & Par diazotation & 0.009 & 0.014 & 0.006 & 0.02 & 0.18 & 0.009 & $\begin{array}{c}0.00 \\
7\end{array}$ & 3.2 \\
\hline Nitrates & $\begin{array}{l}\mathrm{mg} \\
/ \mathrm{L}\end{array}$ & NO3- & $\begin{array}{l}\text { Spectrophoto } \\
\text { mètre }\end{array}$ & $\begin{array}{l}\text { Par réduction } \\
\text { au } \mathrm{Cd}\end{array}$ & 12.25 & 8.07 & 11.34 & 7.26 & 2.92 & 7.03 & 7 & 45 \\
\hline $\begin{array}{c}\text { Ammoni } \\
\text { um }\end{array}$ & $\begin{array}{l}\mathrm{mg} \\
/ \mathrm{L}\end{array}$ & NH4+ & $\begin{array}{l}\text { Spectrophoto } \\
\text { mètre }\end{array}$ & $\mathrm{Au}$ Nessler & 0.2 & 0.03 & 0.04 & 0.15 & 0.12 & 0.07 & 0.04 & \\
\hline Sulfates & $\begin{array}{l}\mathrm{mg} \\
/ \mathrm{L}\end{array}$ & SO42- & $\begin{array}{l}\text { Spectrophoto } \\
\text { mètre }\end{array}$ & Tanin & 0.44 & 0.38 & 0.14 & 0.2 & 17.58 & 2.2 & 0.61 & 500 \\
\hline $\begin{array}{c}\text { Ortho } \\
\text { phosphat } \\
\text { es }\end{array}$ & $\begin{array}{l}\mathrm{mg} \\
/ \mathrm{L}\end{array}$ & PO43- & $\begin{array}{l}\text { Spectrophoto } \\
\text { mètre }\end{array}$ & $\begin{array}{l}\text { Acide } \\
\text { ascorbique }\end{array}$ & 0.19 & 0.22 & 0.22 & 0.35 & 0.08 & 0.09 & $\begin{array}{c}0.00 \\
5\end{array}$ & \\
\hline Fluorides & $\begin{array}{l}\mathrm{mg} \\
/ \mathrm{L}\end{array}$ & F- & $\begin{array}{l}\text { Spectrophoto } \\
\text { mètre }\end{array}$ & SPADNS & $<0.01$ & 0.19 & 0.27 & 0.01 & 0.25 & 0.23 & 0.17 & 1.5 \\
\hline Chlorides & $\begin{array}{l}\mathrm{mg} \\
/ \mathrm{L}\end{array}$ & $\mathrm{Cl}-$ & $\begin{array}{l}\text { Spectrophoto } \\
\text { mètre }\end{array}$ & Mohr & 47 & 14.7 & 10.8 & 14.1 & 105 & 5 & 4.7 & 250 \\
\hline Calcium & $\begin{array}{l}\mathrm{mg} \\
/ \mathrm{L}\end{array}$ & $\mathrm{Ca} 2+$ & Titreur digital & EDTA & 4 & 8.4 & 20.8 & 15.16 & 33.2 & 7.72 & 8.04 & 100 \\
\hline$\underset{\mathrm{m}}{\text { Magnesiu }}$ & $\begin{array}{l}\mathrm{mg} \\
/ \mathrm{L}\end{array}$ & $\operatorname{Mg} 2+$ & Titreur digital & EDTA & 1.21 & 0.7986 & 1.452 & 0.3872 & 10.406 & 3.4364 & $\begin{array}{c}2.68 \\
62\end{array}$ & 50 \\
\hline $\begin{array}{c}\text { Total } \\
\text { hardness }\end{array}$ & $\begin{array}{l}\mathrm{mg} \\
/ \mathrm{L}\end{array}$ & Th & Titreur digital & EDTA & 45 & 24.3 & 58 & 39.5 & 126 & 33.5 & 31.2 & \\
\hline $\begin{array}{c}\text { Carbonat } \\
\text { es }\end{array}$ & $\begin{array}{l}\mathrm{mg} / \\
\mathrm{L}\end{array}$ & CO32- & Titreur digital & A H2SO42- & 0 & 0 & 0 & 0 & 0 & 0 & 5.28 & \\
\hline $\begin{array}{c}\text { Bicarbon } \\
\text { ates }\end{array}$ & $\begin{array}{l}\mathrm{mg} / \\
\mathrm{L}\end{array}$ & $\begin{array}{l}\mathrm{HCO} 3 \\
-\end{array}$ & Titreur digital & A H2SO42- & 14.4 & 39.89 & 68.83 & 49.41 & 66.73 & 24.4 & $\begin{array}{c}33.6 \\
7\end{array}$ & \\
\hline $\begin{array}{l}\text { Mangane } \\
\text { se }\end{array}$ & $\begin{array}{l}\mathrm{mg} \\
/ \mathrm{L}\end{array}$ & $\mathrm{Mn}$ & $\begin{array}{l}\text { Spectrophoto } \\
\text { mètre }\end{array}$ & PAN & 0.027 & 0.006 & 0.048 & 0.086 & 0.037 & 0.007 & $\begin{array}{c}0.00 \\
8\end{array}$ & 0.1 \\
\hline Iron & $\begin{array}{l}\mathrm{mg} \\
/ \mathrm{L}\end{array}$ & $\mathrm{Fe}$ & $\begin{array}{l}\text { Spectrophoto } \\
\text { mètre }\end{array}$ & FerroZine & 0.04 & 0.05 & 0.08 & 0.3 & 0.19 & 0.3 & 0.06 & 0.3 \\
\hline Copper & $\begin{array}{l}\mathrm{mg} \\
/ \mathrm{L}\end{array}$ & $\mathrm{Cu}$ & $\begin{array}{l}\text { Spectrophoto } \\
\text { mètre }\end{array}$ & $\begin{array}{l}\text { Bichinchronina } \\
\text { te }\end{array}$ & 0.05 & 0.02 & 0.12 & 0.11 & 0.14 & 0.04 & 0.07 & 2 \\
\hline Nickel & $\begin{array}{l}\mathrm{mg} \\
/ \mathrm{L}\end{array}$ & $\mathrm{Ni}$ & $\begin{array}{l}\text { Spectrophoto } \\
\text { mètre }\end{array}$ & PAN & 0.021 & $<0.001$ & $\begin{array}{c}<0.00 \\
1\end{array}$ & 0.013 & $\begin{array}{c}<0.00 \\
1\end{array}$ & $\begin{array}{c}<0.00 \\
1\end{array}$ & $\begin{array}{c}0.01 \\
7\end{array}$ & 0.02 \\
\hline Cobalt & $\begin{array}{l}\mathrm{mg} \\
/ \mathrm{L}\end{array}$ & Co & $\begin{array}{l}\text { Spectrophoto } \\
\text { mètre }\end{array}$ & PAN & 0.097 & 0.004 & 0.035 & 0.058 & 0.019 & $\begin{array}{c}<0.00 \\
1\end{array}$ & $\begin{array}{c}0.06 \\
4\end{array}$ & \\
\hline Lead & $\begin{array}{l}\mu \mathrm{g} / \\
\mathrm{L}\end{array}$ & $\mathrm{Pb}$ & $\begin{array}{l}\text { Spectrophoto } \\
\text { mètre }\end{array}$ & Ditizone & 4.64 & 2.99 & 2.98 & 20.75 & 1.41 & 13.71 & 2.77 & 50 \\
\hline $\begin{array}{c}\text { Cadmiu } \\
\text { m }\end{array}$ & $\begin{array}{l}\mu \mathrm{g} / \\
\mathrm{L}\end{array}$ & $\mathrm{Cd}$ & $\begin{array}{l}\text { Spectrophoto } \\
\text { mètre }\end{array}$ & Ditizone & 0.53 & 0.741 & 0.624 & 0.707 & 1.319 & 1.634 & $\begin{array}{c}2.57 \\
3 \\
\end{array}$ & 5 \\
\hline
\end{tabular}

Source: SOHOUNOU, in November, 2016; results of analysis of the Laboratory (LCQEA)

Red: Value to be monitored

The analysis in Table II shows that Well 2 and tank 1 have an iron concentration equal to the national standard compared to other sources. Unlike, Drill 1 with a nitrate concentration of $12.25 \mathrm{mg} / 1$, Well 3 contains a high concentration of $0.18 \mathrm{mg} / \mathrm{L}$ for nitrite. The presence of nitrates in drinking water is mainly due to human activities (Saâdia and al., 2007). They 
can also be linked to the bacterial oxidation of ammonia (Bengoumi and al., 2004).

Concerning cations, calcium, magnesium and total hardness levels vary considerably from one well to another. Calcium is more concentrated at well 3, i.e $33.2 \mathrm{mg} / \mathrm{L}$. Magnesium also remains high in well 3 (10.40mg / L) compared with other water sources. For the total well hardness, well 3 remains high at $126 \mathrm{mg} / \mathrm{L}, 45 \mathrm{mg} / \mathrm{L}$ for drilling 1 and $33.5 \mathrm{mg} / \mathrm{L}$ for tank 1. Carbonate is present at the level of the well, tank 2 compared to other water points where it is absent.

The results showed that the concentration of iron, copper, nickel and cobalt remains low. Well 2 and tank 1 are concentrated in lead, respectively $20.75 \mathrm{mg} / \mathrm{L}$ and $13.71 \mathrm{mg} / \mathrm{L}$. Tank 1 and 2 have a high cadmium concentration compared to other sampled water points. Toxic metals are numerous, but mostly cadmium and lead. They have impacts on consumer products such as water by humans (Nduka and $a l$., 2008). Heavy metals are pollutants generated by human activity and have a high toxicological impact (Azeez and al., 2009).

In sum, the concentration of chemical elements in drinking water is related to the intensive agricultural practices of the pineapple crop in the study area. These results show that water points are polluted by chemical elements even if they are weak. Water monitoring and awareness efforts can help people better protect their sources of drinking water.

\section{Microbiological quality of sampled waters}

The results of microbiological analysis of the water of the wells, boreholes and tank in the municipality of Allada are recorded in Table III.

Table III: Results of analysis of microbiological parameters

\begin{tabular}{|c|c|c|c|c|c|c|c|c|c|c|c|c|}
\hline Settings & $\begin{array}{c}\text { Un } \\
\text { it }\end{array}$ & $\begin{array}{c}\text { Symb } \\
\text { ol }\end{array}$ & Appliances & Methods & $\begin{array}{c}\text { Drillin } \\
\text { g } 1\end{array}$ & $\begin{array}{c}\text { Drillin } \\
\text { g } 2\end{array}$ & Well1 & Well2 & $\begin{array}{c}\text { Well } \\
\mathbf{3}\end{array}$ & $\begin{array}{c}\text { Tank } \\
\mathbf{1}\end{array}$ & $\begin{array}{l}\text { Tan } \\
\mathrm{k} \mathbf{2}\end{array}$ & $\begin{array}{l}\text { Nation } \\
\text { al } \\
\text { Standar } \\
\text { d }\end{array}$ \\
\hline Nitrites & $\begin{array}{c}\mathrm{mg} \\
/ \mathrm{L}\end{array}$ & NO2- & $\begin{array}{l}\text { Spectrophoto } \\
\text { mètre }\end{array}$ & $\begin{array}{l}\text { Par } \\
\text { diazotation }\end{array}$ & 0.009 & 0.014 & 0.006 & 0.02 & 0.18 & 0.009 & $\begin{array}{c}0.00 \\
7\end{array}$ & 3.2 \\
\hline Nitrates & $\mathrm{mg}$ & NO3- & $\begin{array}{l}\text { Spectrophoto } \\
\text { mètre }\end{array}$ & $\begin{array}{l}\text { Par réduction } \\
\text { au Cd }\end{array}$ & 12.25 & 8.07 & 11.34 & 7.26 & 2.92 & 7.03 & 7 & 45 \\
\hline $\begin{array}{c}\text { Ammoni } \\
\text { um }\end{array}$ & $\begin{array}{c}\mathrm{mg} \\
/ \mathrm{L}\end{array}$ & NH4+ & $\begin{array}{l}\text { Spectrophoto } \\
\text { mètre }\end{array}$ & Au Nessler & 0.2 & 0.03 & 0.04 & 0.15 & 0.12 & 0.07 & 0.04 & \\
\hline Sulfates & $\mathrm{mg}$ & $\begin{array}{l}\mathrm{SO} 42 \\
-\end{array}$ & $\begin{array}{l}\text { Spectrophoto } \\
\text { mètre }\end{array}$ & Tanin & 0.44 & 0.38 & 0.14 & 0.2 & 17.58 & 2.2 & 0.61 & 500 \\
\hline $\begin{array}{c}\text { Ortho } \\
\text { phospha } \\
\text { tes }\end{array}$ & $\begin{array}{c}\mathrm{mg} \\
/ \mathrm{L}\end{array}$ & $\begin{array}{l}\mathrm{PO} 43 \\
-\end{array}$ & $\begin{array}{l}\text { Spectrophoto } \\
\text { mètre }\end{array}$ & $\begin{array}{l}\text { Acide } \\
\text { ascorbique }\end{array}$ & 0.19 & 0.22 & 0.22 & 0.35 & 0.08 & 0.09 & $\begin{array}{c}0.00 \\
5\end{array}$ & \\
\hline $\begin{array}{c}\text { Fluoride } \\
\text { s }\end{array}$ & $\begin{array}{l}\mathrm{mg} \\
/ \mathrm{L}\end{array}$ & F- & $\begin{array}{l}\text { Spectrophoto } \\
\text { mètre }\end{array}$ & SPADNS & $<0.01$ & 0.19 & 0.27 & 0.01 & 0.25 & 0.23 & 0.17 & 1.5 \\
\hline $\begin{array}{c}\text { Chloride } \\
\text { s }\end{array}$ & $\mathrm{mg}$ & $\mathrm{Cl}-$ & $\begin{array}{l}\text { Spectrophoto } \\
\text { mètre }\end{array}$ & Mohr & 47 & 14.7 & 10.8 & 14.1 & 105 & 5 & 4.7 & 250 \\
\hline Calcium & $\mathrm{mg}$ & $\mathrm{Ca} 2+$ & $\begin{array}{l}\text { Titreur } \\
\text { digital }\end{array}$ & EDTA & 4 & 8.4 & 20.8 & 15.16 & 33.2 & 7.72 & 8.04 & 100 \\
\hline Magnesi & $\mathrm{mg}$ & Mg2+ & Titreur & EDTA & 1.21 & 0.7986 & 1.452 & 0.387 & 10.40 & 3.436 & 2.68 & 50 \\
\hline
\end{tabular}




\begin{tabular}{|c|c|c|c|c|c|c|c|c|c|c|c|c|}
\hline um & $/ \mathrm{L}$ & & digital & & & & & 2 & 6 & 4 & 62 & \\
\hline $\begin{array}{c}\text { Total } \\
\text { hardness }\end{array}$ & $\begin{array}{c}\mathrm{mg} \\
/ \mathrm{L}\end{array}$ & Th & $\begin{array}{l}\text { Titreur } \\
\text { digital }\end{array}$ & EDTA & 45 & 24.3 & 58 & 39.5 & 126 & 33.5 & 31.2 & \\
\hline $\begin{array}{c}\text { Carbona } \\
\text { tes }\end{array}$ & $\mathrm{mg}$ & $\mathrm{CO} 32$ & $\begin{array}{l}\text { Titreur } \\
\text { digital }\end{array}$ & A H2SO42- & 0 & 0 & 0 & 0 & 0 & 0 & 5.28 & \\
\hline $\begin{array}{c}\text { Bicarbo } \\
\text { nates }\end{array}$ & $\begin{array}{l}\mathrm{mg} \\
/ \mathrm{L}\end{array}$ & $\begin{array}{l}\mathrm{HCO} \\
3-\end{array}$ & $\begin{array}{l}\text { Titreur } \\
\text { digital }\end{array}$ & A H2SO42- & 14.4 & 39.89 & 68.83 & 49.41 & 66.73 & 24.4 & $\begin{array}{c}33.6 \\
7\end{array}$ & \\
\hline $\begin{array}{l}\text { Mangan } \\
\text { ese }\end{array}$ & $\begin{array}{l}\mathrm{mg} \\
/ \mathrm{L}\end{array}$ & $\mathrm{Mn}$ & $\begin{array}{l}\text { Spectrophoto } \\
\text { mètre }\end{array}$ & PAN & 0.027 & 0.006 & 0.048 & 0.086 & 0.037 & 0.007 & $\begin{array}{c}0.00 \\
8\end{array}$ & 0.1 \\
\hline Iron & $\begin{array}{c}\mathrm{mg} \\
/ \mathrm{L}\end{array}$ & $\mathrm{Fe}$ & $\begin{array}{l}\text { Spectrophoto } \\
\text { mètre }\end{array}$ & FerroZine & 0.04 & 0.05 & 0.08 & 0.3 & 0.19 & 0.3 & 0.06 & 0.3 \\
\hline Copper & $\begin{array}{l}\mathrm{mg} \\
/ \mathrm{L}\end{array}$ & $\mathrm{Cu}$ & $\begin{array}{l}\text { Spectrophoto } \\
\text { mètre }\end{array}$ & $\begin{array}{l}\text { Bichinchronin } \\
\text { ate }\end{array}$ & 0.05 & 0.02 & 0.12 & 0.11 & 0.14 & 0.04 & 0.07 & 2 \\
\hline Nickel & $\begin{array}{c}\mathrm{mg} \\
/ \mathrm{L}\end{array}$ & $\mathrm{Ni}$ & $\begin{array}{l}\text { Spectrophoto } \\
\text { mètre }\end{array}$ & PAN & 0.021 & $<0.001$ & $\begin{array}{c}<0.00 \\
1\end{array}$ & 0.013 & $\begin{array}{c}<0.00 \\
1\end{array}$ & $\begin{array}{c}<0.00 \\
1\end{array}$ & $\begin{array}{c}0.01 \\
7\end{array}$ & 0.02 \\
\hline Cobalt & $\mathrm{mg}$ & Co & $\begin{array}{l}\text { Spectrophoto } \\
\text { mètre }\end{array}$ & PAN & 0.097 & 0.004 & 0.035 & 0.058 & 0.019 & $\begin{array}{c}<0.00 \\
1\end{array}$ & $\begin{array}{c}0.06 \\
4\end{array}$ & \\
\hline Lead & $\begin{array}{l}\mu \mathrm{g} / \\
\mathrm{L}\end{array}$ & $\mathrm{Pb}$ & $\begin{array}{l}\text { Spectrophoto } \\
\text { mètre }\end{array}$ & Ditizone & 4.64 & 2.99 & 2.98 & 20.75 & 1.41 & 13.71 & 2.77 & 50 \\
\hline $\begin{array}{c}\text { Cadmiu } \\
\text { m }\end{array}$ & $\begin{array}{l}\mu \mathrm{g} / \\
\mathrm{L}\end{array}$ & $\mathrm{Cd}$ & $\begin{array}{l}\text { Spectrophoto } \\
\text { mètre }\end{array}$ & Ditizone & 0.53 & 0.741 & 0.624 & 0.707 & 1.319 & 1.634 & $\begin{array}{c}2.57 \\
3 \\
\end{array}$ & 5 \\
\hline
\end{tabular}

Source: SOHOUNOU, in November, 2016; results of analysis of the Laboratory (LCQEA)

Legend: $\mathrm{SONEB}=$ Benin's national water company

From the analysis in table III, it appears that drinking water sources in the study area are highly microbiologically contaminated as they show indicators of fecal contamination.

Almost all the pathogenic microorganisms that can be found in drinking water come from human or animal feces. The results revealed the presence of the presumed coliforms in all the waters sampled except for the water of the tank 2. Its presence in the water of SoNEB at the catchment is due either to the transport, to the sampling conditions or to the manipulations in Laboratory because the national standard provides 0 UFC in $100 \mathrm{~mL}$.

The presence of Escherichia coli with a high concentration at home SONEB (39 UFC) and at the well 2 level $\left(7.10^{2}\right.$ UFC) was revealed.

E. coli bacteria belong to the group of total coliforms and indicate fecal pollution. It is a very abundant species in the human and animal intestinal flora, and it is also the only one that is strictly of fecal origin. The presence of these faeces in the open air can be explained by a faulty septic installation coupled with insalubrity around the water points. Similarly, it is also linked to the application of organic manure in pineapple fields, which could contribute to the growth of certain germs. The lack of protective and precautionary measures may favor the proliferation of these bacteria in drinking water. Therefore, Gundry and al., 2009 suggest taking the necessary steps to ensure the safe and efficient functioning of a drinking water supply system. 


\section{Discussion}

The results corroborate those of Degbey et al. (2008) who worked on well water quality in the commune of Abomey-Calavi. The nitric pollution of the groundwater studied is due to the application of manure or chemical fertilizers, as well as to nearby septic installations of water points. These abnormal nitrate contents obtained in well water are similar to those obtained by Laafou et al. (2013) in the spring waters of the El Hajeb region of Morocco and also those reported by El Kharmouz et al. (2013) in the groundwater of the city of Oujda (Morocco).

The presence of Escherichia coli is an evidence of fecal pollution in drinking water. These results are similar to those found at the level of the water table of M'nassra in Morocco Bricha (2007), the high concentration of microbial germs in the different supply systems could be explained by the poor protection of these systems. Moreover, Mpakam et al. (2006) showed that the relationship between the position of the source of pollution in relation to the drinking-water supply structure or the source is very significant and the distance between the two (Systems / sources and latrine / place of defecation).

\section{Conclusion}

The physicochemical and microbiological results showed a contamination of the well water that is used by the populations as drinking water in the municipality of Allada.

From a microbiological point of view, the sources of drinking water studied have high concentrations of fecal contamination germs because they contain Escherichia coli bacteria. These germs testify to contamination of the water by human or animal dejections. This constitutes a health threat to the populations of Allada, for whom the water of wells, boreholes and tank are necessary for most of their needs.

To avoid health risks it is necessary to:

$\checkmark \quad$ family water treatment through the use of Aquatab produuct to treat drinking water,

$\checkmark \quad$ extend the rural drinking water network,

$\checkmark \quad$ extend the sewage network for the disposal of wastewater and waste of all kinds,

$\checkmark \quad$ maintain the vicinity of wells to avoid fecal contamination.

\section{References:}

1. Azeez J O, Adekunle I O, Atiku O O, Akande KB, Jamiu, Azeez S O. (2009): Effect of nineyears of animal wastedeposition on profile distribution of heavymetals in Abeokuta, south-western Nigeria and 
its implication for environmental quality. Waste. Man., 29 (9): 25826.

2. Bengoumi M. et al. (2004): Quality of water in poultry farming. Quarterly review of scientific and technical information - Volume 3 $\mathrm{N}^{\circ} 1$, Morocco, 5-25pp.

3. Bricha S. (2007): Study of the physico-chemical and bacteriological quality of the groundwater table M'nasra (Morocco), Africa Science Review 03 (3), 391-404.

4. Dégbey C, Makoutodé M, Ouendo EM, Fayomi B, De Brouwer C. (2008): The quality of well water in the commune of Abomey-Calavi in Benin. Environment. Risks. Health, 7 (4): 279-283

5. Degbey C, Makoutode E. M., Ouendo C., De Brouwer (2010): Physico-chemical and microbiological water well pollution in the Abomey-Calavi ùunicipality of Benin in 2009. Int. J. Biol. Chem. Sci. 4 (6): 2257-2271, December 2010

6. Gundry SW, Wright JA, Conroy RM, Preez MD, Genthe B, Moyo S Mutisi C, PotgieterN. 2009: Child dysentery in the Limpopo Valley: acohortstudy of water, sanitation and hygieneiskfactors. J.Water. Health. , 7 (2): 259-66.

7. Festy B., Hartemann P., Ledrans M., Levallois P., Payment P., Tricard D., 2003. Water quality. In: Environment and Public Health Foundations and Practices. 333-368.

8. Hassoune El M., El kettani S., Koulali Y., Bouzidi A. Bacteriological contamination of ground water from Settat-city, Morocco. Rev. Microbiol. Ind. San and Environn. 1 (2010) 1-21.

9. Jean RODIER, Bernard LEGUBE, Nicole MERLET et al. (2009): Water Analysis, Dunod Paris, 1959, for the first edition

10. MPAKAM H.G., KAMGANG KABEYENE B.V., KOUAM KENMOGNE G.R., BEMMO N., EKODECK G.E., (2006): Access to drinking water and sanitation in the cities of developing countries (case of Bafoussam in Cameroon). Vertigo, Journal of Environmental Science, Vol 7, No. 2, Art 12, September 2006, 10p. (Www.vertigo.uqam.ca/vol7n2/art12vol7n2/form_article).

11. NAIRAIN S. (2002): The toilet with hunting is ecologically "badly thought". Down to Earth, Vol. 10, No. 19, February 28, 19p. (Www.tu-harburg.de/susan/downloads/theflushtoilet-en.pdf.

12. EL KHARMOUZ M., SBAA M., CHAFI A., SAADI S. (2013). The study of the impact of leachate from the old rubbish dump in the city of Oujda (eastern Morocco) on the physicochemical quality of ground and surface water. Larhyss Journal, No. 16, 105-119.

13. LANOIX J.N. and ROY, M.L., 1976. Manual of the health technician. WHO, Geneva. 21.55. 
14. LAAFOU S., ABDALLAOUI A., EL ABID A. (2013). Study of the physicochemical quality of the waters of certain sources in the El Hajeb regionScienceLib., Editions Mersenne, 5, 130603.

15. WHO (2000): Nutrient minerals in drinking-water and the potential health consequences of long-term consumption of demineralized and remineralized mineral content drinking-waters.

16. World Health Organization (WHO). The WHO guidelines for drinking water quality, the baseline for drinking water safety, updated in 2006.

17. Tanouayi G., Gnandi K., Ahoudi H., Ouro-Sama K. (2015): metal contamination of surface water and groundwater in the mining area of Hahotoe-Kpogame phosphates (South Togo) : Case of cadmium, lead, copper and nickel, Larhyss Journal, ISSN 1112-3680, No. 21, March 2015, pp. 35-50

18. Nduka JK, Orisakwe OE, Ezenweke LO, ChendoMN, Ezenwa TE (2008): Heavy metal contamination of foods by refuse dump sites in Awka, southeastern Nigeria. Scientific. World .Journal. , 8: 941-8.

19. Saadia B, Khadija O, Said O, Nourredine EH, Benaissa A. (2007): Study of the physicochemical and bacteriological quality of the groundwater table M'nasra (Morocco). Africa Science, 03 (3): 391404. 